\title{
ANALISIS PENGARUH TRANSAKSI DIGITALISASI UANG ELEKTRONIK TERHADAP CASHLESS SOCIETY DAN INFRASTRUKTUR UANG ELEKTRONIK SEBAGAI VARIABEL PEMODARASI
}

\section{ANALYSIS OF THE EFFECT OF DIGITALIZATION OF ELECTRONIC MONEY TRANSACTIN ON CASHLESS SOCIETY AND ELECTRONIC MONEY INFRASTRUCTURE AS A MODERATING VARIABLE}

\author{
Tumpal Manik \\ Universitas Maritim Raja Ali Haji - Tanjungpinang \\ Email : tmanyk@gmail.com dan tmanik@umrah.ac.id
}

\begin{abstract}
Abstrak
Penelitian ini bertujuan untuk menguji dan melakukan analisis pengaruh digitalisasi transaksi uang elektronik terhadap cashless society dan infrastruktur uang elektronik sebagai variabel pemodarasi. Jenis penelitian ini adalah penelitian kualitatif, menggunakan data sekunder dalam bentuk time series sejak Januari 2014 - Juni 2019, jumlah data sebanyak 66 data diperoleh dari publikasi website Bank Indonesia. Pengolahan data diuji dengan aplikasi statistik melalui uji asumsi klasik, uji-t, uji-f dan uji determinasi. Hasil pengujian menunjukkan bahwa variabel yang berpoengaruh signifikan terhadap chesless social terdiri dari: 1) transaksi uang elektronik berpengaruh signifikan sebesar 0,$929 ; 2$ ) uang elektronik beredar berpengaruh signifikan sebesar $-1,470$; 3) digitalisasi uang elektronik berpengaruh signifikan sebesar $-0,543$; 4) infrastruktur uang elektronik berpengaruh signifikan sebesar -1,463; 5) secara simultan memiliki berpengaruh sebesar $74,4 \%$. Sedangkan infrastruktur uang elektronik sebagai variabel pemoderasi yang memperkuat pengaruh transaksi uang elektronik terhadap cashless society sebesar $27,6 \%$.
\end{abstract}

Kata kunci : Digitalisasi uang elektronik, cashless society dan infrastruktur

\begin{abstract}
This research aims to examine and analyze the effect of digitizing electronic money transactin on cashless society and electronic money infrastructure as a moderating variable. This type of research is a qualitative study, using secondary data in the form of time series from January 2014 - June 2019, a total of 66 data obtained from the publication of the website of Bank Indonesia. Data processing was tested with statistical applications through the classic assumption test, $t$-test, f-test and determination test. The test results indicate that the variables that have a significant effect on cashless society; 1) electronic money transactions have a significant effect of 0.929; 2) electronic money supply has a significant effect of $-1,470 ; 3$ ) digitalization of electronic money has a significant effect of $-0,543$; 4) electronic money infrastructure has a significant effect of $-1,463 ; 5)$ simultaneously has an effect of $74.4 \%$. While electronic money infrastructure as a moderating variable that strengthens the effect of electronic money transactions on cashless society by $27.6 \%$.
\end{abstract}

Keywords: Digitalization of electronic money, cashless society and infrastructure 


\section{PENDAHULUAN}

Perkembangan sistem pembayaran berinovasi dari tahun ke tahun dampak dari kemajuan teknologi informasi, seiring dengan kemajuan sistem digitalisasi jasa keuangan dan instrumeninstrumen transaksi pembayaran. Inovasi sistem pembayaran pada awalnya sistem manual/konvensional harus membawa fisik uang dan ikut antrian di loket pembayaran bank, kemudian berinovasi menjadi sistem pembayaran dengan instrumen non tunai memakai APMK (Alat Pembayaran Menggunakan Kartu) seperti kartu ATM/Debet dan kartu kredit, kini telah bertransformasi dengan inovasi terbaru yaitu digitalisasi sistem pembayaran dengan model uang elektronik (e-electronic).

Transformasi transaksi pembayaran secara elektronik terdiri dari beberapa model, antara lain; transfer langsung (electronic funds transfer), menggunakan kartu pembayaran (payment card), menggunakan uang elektronik (electronic money) dan uang digital (digital money). Perbedaan model penyimpanan nilai uang digitalisasi dengan uang elektronik yaitu dalam uang digital tidak memiliki nilai instrinsik dan tidak berwujud diterbitkan sebagai pengganti uang konvensional, dapat berdiri sendiri dan penerbitannya tidak berdasarkan pada uang konvensional, sedangkan uang elektronik bentuk uang tanpa uang fisik (cashless money) yang menyimpan nilai uang dalam bentuk data digital. Hal ini berbeda juga dengan APMK, dengan kartu ATM/Debit, nilai uang disimpan dalam rekening pemilik kartu.

Sejak bulan Juli 2009, di Indonesia mulai berkembang perusahaan penyelenggara uang elektronik dengan produk dari server based dan chip based pada institusi perbankan dan lembaga selain bank setelah memperoleh izin dari Bank Indonesia berdasarkan Peraturan tentang e-money diatur dalam Peraturan Bank Indonesia Nomor 11/12/PBI/2009 tentang Uang Elektronik (electronic money). Statistik perusahaan penerbit e-money yang telah memperoleh izin dari Bank Indonesia hingga 24 Mei 2019 ada 38 perusahaan, antara lain : tahun 2009 ada 9 perusahaan, tahun 2010-2015 bertambah 11 perusahaan, Januari 2016 sampai tanggal 24 Mei 2019 bertambah 18 perusahaan, data ini membuktikan bahwa pertumbuhan penggunaan uang elektronik di Indonesia telah meningkat.

Selain peningkatan perusahaan penyelenggara uang elektronik, pertumbuhan volume uang elektronik juga menjadi bukti pendukung dalam mengendalikan stabilitas sistem keuangan. Volume pertumbuhan uang elektronik lima tahun terkahir, sejak tahun 2015 sebesar 163,35\%, tahun 2016 sebesar 27,55\%, tahun 2017 sebesar 38,09\%, tahun 2018 sebesar 209, 83\%, data ini membuktikan bahwa volume pertumbuhan uang elektronik setiap tahuannya adalah positif dan menjadi bagian dari perputaran ekonomi masyarakat untuk menjaga stabilitas sistem keuangan di indonesia.

Jumlah uang elektronik beredar selama lima tahun terakhir mengalami pertumbuhan positif, yakni tahun 2015 sebesar 19,20\%, tahun 2016 sebesar 4,60\% tahun 2017 sebesar 67,3\%, tahun 2018 sebesar 84,90\% dan tahun 2019 diprediksi mencapai angka minimal sebesar $59,03 \%$. Pertumbuhan jumlah uang elektronik dimasyarakay dapat kita lihat dari jumlah pertumbuhan peredaran uang elektronik setiap tahun. Selain pertumbuhan peredaran uang elektronik, kita dapat melihat pertumbuhan peredaran uang Kartal diuar Bank Umum ditambah Uang Giral disebut peredaran uang sempit (M1), antara lain tahun 2015 sebesar 10,88\%, tahun 2016 sebesar 12,12\% tahun 2017 sebesar 13,96\%, tahun 2018 sebesar 8,62\% dan tahun 2019 diprediksi mencapai angka sebesar $11,25 \%$, sedangkan pertumbuhan uang beredar luas (M2) lima tahun terakhir yaitu tahun 2015 sebesar 12,65\%, tahun 2016 sebesar 7,82\% tahun 2017 sebesar 9,89\%, tahun 2018 sebesar 6,88\%. Sama hanya dengan jumah Uang Beredar Luas (M2) setiap tahun mengalami pertumbuhan positif. 
Penggunaan instrumen pembayaran dengan APMK mengalami pertumbuhan positif setiap tahun. Pertumbuhan APMK dengan kartu ATM/Debit pada tahun 2015 sebesar 12,18\%, tahun 2016 sebasar 13,60\%, tahun 2017 sebesar 9,56\%, tahun 2018 sebesar $13,53 \%$ dan tahun 2019 diprediksi sebesar 14,01\%. APMK dengan Kartu Kredit juga mengalami pertumbuhan positif yaitu pada tahun 2015 sebesar 10,62\%, tahun 2016 sebasar 8,43\%, tahun 2017 sebesar $7,32 \%$, tahun 2018 sebesar $3,53 \%$ dan tahun 2019 diprediksi sebesar 7,57\%. Berdasarkan datadata uang elektronik dan APMK, terjadi pertumbuhan yang posistip, kenyataannya masyarakat Indonesia masih dominan melakukan transaksi secara manual atau konvensional dan belum terbiasa mengguankan uang elektronik.

Pemerintah selalu berupaya mengurangi jumlah fisik uang beredar di masyarakat, hal ini dilakukan dengan maksud untuk menggalakkan penggunaan sistem digitalisasi dan uang elektronik, khususnya Bank Indonesia telah menerbitkan Peraturan Bank Indonesia Nomor 11/12/PBI/2009 Tentang Uang Elektronik (Electronic Money), Lembaran Negara Republik Indonesia Tahun 2009 Nomor 65, Tambahan Lembaran Negara Republik Indonesia Nomor 5001. Peraturan Bank Indonesia Nomor 18/17/PBI/2016 Tentang Perubahan Kedua Atas Peraturan Bank Indonesia Nomor 11/12/PBI/2009 Tentang Uang Elektronik (Lembaran Negara Republik Indonesia Tahun 2016 Nomor 179, Tambahan Lembaran Negara Republik Indonesia Nomor 5925). Penggunaan uang elektronik akan menciptakan sistem pembayaran yang lebih modern dan efisien, efektif dana aman, sehingga masyarakat akan mempertimbangkan uang elektronik sebagai pilihan utama.

Digitalisasi jasa keuangan sebagai transformasi perkembangan uang elektronik yang ditawarkan kepada kemasyarkat menjadi bagian penggerak pertumbuhan perekonomian dari sektor perbankan menuju cashless society. Hal ini diperkuat dengan visi yang uraikan oleh Gubernur BI ada 5 visi sebagai respon perkembangan digitalisasi yang mengubah lanskap risiko secara signifikan, yaitu 1) mendukung integrasi ekonomi-keuangan digital nasional, 2) mendukung digitalisasi perbankan sebagai lembaga utama ekonomi-keuangan, 3) menjamin interlink antara fintech dengan perbankan, 4) menjamin keseimbangan antara inovasi dengan consumers protection, integritas dan stabilitas, 5) menjamin kepentingan nasional dalam ekonomi keuangan digital antar Negara (Warjiyo, 2019).

Menjaga stabilitas sistem keuangan menjadi tujuan program pemerintah, khusunya institusi perbankan, sedangkan pemantauan stabilitas keuangan merupakan tugas bank sentral dalam menjaga stabilitas keuangan berdasarkan dua indikator, yakni indikator mikroprudensial dan makroekonomi yang saling melengkapi sebagai aksi dan reaksi dalam sistem keuangan dan ekonomi untuk meningkatkan perannya sebagai motor penggerak pertumbuhan ekonomi, mengupayakan kondisi sektor keuangan sehat dan kuat dalam menghadapi gejolak pada institusi keuangan atau pasar keuangan. Berdasarkan latar belakang diatas, maka peneliti tertarik melakukan penelitian dan menetapkan judul yaitu Analisis Pengaruh Digitalisasi Jasa Keuangan dengan Uang Elektronik, Cashless Society dan Instrumen Pembayaran Non Tunai Terhadap Stabilitas Sistem Keuangan.

Digital jasa keuangan tak hanya mendorong pertumbuhan ekonomi di Indonesia, namun juga diharapkan mampu menjaga sistem keuangan yang stabil, maka tujuan penelitian ini adalah; 1) Apakah transaksi uang elektronik berpengaruh terhadap chesless social ? 2) Apakah uang elektronik beredar berpengaruh terhadap chesless social ? 3) Apakah digitalisasi uang elektronik berpengaruh terhadap chesless social ? 4) Apakah infrastruktur uang elektronik berpengaruh terhadap chesless social ? 6) Apakah secara parsial transaksi uang elektronik, uang elektronik beredar, digitalisasi uang elektronik berpengaruh terhadap chesless social yang dimoderasi infrastruktur uang elektronik? 


\section{LANDASAN TEORI}

\section{Digitalisasi Uang Elektronik}

Menghadapi tuntutan dunia bisnis perbankan yang semakin kompetitif, khususnya tuntutan sistem layanan perbankan harus lebih efisian dan efektif, sehingga adanya peralihan layanan dari sistem konvensioal atau manual menjadi sistem non tunai hingga sistem digitalisasi dengan uang elektronik. Penerapan sistem digitalisasi jasa keuangan untuk mempermudah arus lalu lintas transaksi pembayaran dengan perbankan, maka para ahli teknologi informasi berkolaborasi dengan perbankan menciptakan aplikasi perbankan sebagai apalikasi layanan perbankan, aplikasi elektronik perbankan bentuk teknologi digitalisasi jasa keuangan. Saat ini, layanan perbankan dengan sentuhan digitalisasi seperti automatic teller machine, sms banking, internet banking, mobile banking, sampai dengan produk digital dikembangkan bertujuan meningkatkan pelayanan perbankan serta sebagai fasilitas mempermudah bertransaksi dengan jasa keuangan khususnya perbankan.

Perkembangan teknologi dan digitalisasi jasa keuangan terus berinovasi dengan cepat untuk mempengaruhi pola hidup dan pola pikir masyarakat. Hal itu juga berpengaruh pada pola bisnis, yang mengarah ke digitalisasi dan ada beberapa langkah yang harus dilakukan perbankan untuk menyukseskan digital banking. Pertama, perbankan harus menyediakan media penghubung antara layanan fintech dan layanan perbankan. Kedua, perbankan harus menyiapkan proses bisnis digitalnya. Ketiga, perbankan harus menciptakan customer experience dan operational excellence melalui pemanfaatan data (Hassim, 2017).

Teknologi digital memberi kemudahan bagi perbankan dan nasabah untuk mengakses informasi melalui transaksi online, layanan keuangan hanya melalui genggaman tangan. Seiring dengan perkembangan dalam era digitalisasi, para pelaku bisnis bidang keuangan harus mampu mengikuti perkembangan era tersebut untuk menghasilkan dan menciptakan model bisnis baru dan memberikan peluang baru yang menghasilkan nilai, sehingga digitalisasi dapat dilihat sebagai suatu peluang bisnis untuk meningkatkan hubungan pelanggan, proses bisnis, menciptakan dan mengadaptasi model bisnis baru, peluang bagi perusahaan dan organisasi untuk meningkatkan aktivitas bisnis mereka, (Schumann, 2015).

Gubernur Bank Indonesia mengatakan, ada 5 visi yang dibuat sebagai respon atas perkembangan digitalisasi yang mengubah lanskap risiko secara signifikan, yaitu 1) mendukung integrasi ekonomi-keuangan digital nasional sehingga menjamin fungsi bank sentral dalam proses peredaran uang, kebijakan moneter, dan stabilitas sistem keuangan, serta mendukung inklusi keuangan, 2) mendukung digitalisasi perbankan sebagai lembaga utama dalam ekonomikeuangan digital melalui open-banking maupun pemanfaatan teknologi digital dan data dalam bisnis keuangan, 3) menjamin interlink antara Fintech dengan perbankan untuk menghindari risiko shadow banking melalui pengaturan teknologi digital (Application Programming Interface$A P I)$, kerjasama bisnis, maupun kepemilikan perusahaan, 4) menjamin keseimbangan antara inovasi dengan consumers protection, integritas dan stabilitas serta persaingan usaha yang sehat, 5) menjamin kepentingan nasional dalam ekonomi-keuangan digital antar negara melalui kewajiban pemrosesan semua transaksi domestik di dalam negeri dan kerjasama penyelenggara asing dengan domestik, dengan memperhatikan prinsip resiprokalitas (Warjiyo, 2019).

Perkembangan sistem pembayaran digitalisasi secara langsung berdampak pada industri perbankan, sebab perkembangan teknologi digital dalam industri perbankan dapat dilihat sebagai kesempatan maupun tantangan, dan perkembangan digitalisasi perbankan menghadapai dua perubahan dalam perbankan antara lain : pertama yang akan berdampak pada industri perbankan adalah perilaku nasabah yang berpindah dari aktivitas transaksi 
konvesional, seperti pergi ke bank untuk menabung, ke transaksi digital, kedua adalah peran fintek yang saat ini hanya berfungsi sebagai pengumpul data pengguna dan menjadi pusat induk data besar, ke depannya akan sangat mungkin jika fungsi mereka akan sama persis dengan bank, sebab bank memiliki wewenang untuk melakukan sistem pembayaran sedangkan fintek memiliki kemajuan teknologi dari segi kemampuan analisis data pengguna (Basri, 2018).

\section{Uang Elektronik (Electronic Money)}

Uang elektronik (e-money) hadir di Indonesia sejak tahun 2009, sebagai alternatif transaksi elektronik menggantikan sistem uang tunai yang diterbitkan oleh pihak perbankan dan lembaga selain bank atas izinan dari Bank Indonesia berdasarkan Peraturan Bank Indonesia Nomor 11/12/PBI/2009 tentang uang elektronik (electronic money). Perkembangan perusahaan penerbit e-money yang telah memperoleh izin dari Bank Indonesia per 24 Mei 2019 ada 38 perusahaan, antara lain : tahun 2009 ada 9 perusahaan, tahun 2010-2015 bertambah 11 perusahaan, tahun 2016 - 24 Mei 2019 bertambah 18 perusahaan, dengan fasilitas nama produk server based dan chip based, hal ini membuktikan bahwa perkembangan sistem uang elektronik di Indonesia mampu merubah pola model bisnis keuangan, dimana melemahnya barrier to entry memberikan peran bagi fintech dalam memunculkan perilaku unregulated yang menjalankan model bisnis layaknya perusahaan atau institusi regulated. Sistem e-money membuktikan bahwa di Indonesia menggunakan transaksi pembayaran dengan e-money sudah diimplementasikan.

Seiring dengan perkembangan perusahaan penerbit e-money memberikan kemudahan bertransaksi dan banyaknya pilihan sistem transaksi digital, masyarakat yang menggunakan transaksi e-money seharusnya menjadi hal yang umum digunakan dalam kehidupan sehari-hari, khususnya dunia bisnis menghendaki banyak pihak bertransaksi dengan sistem modern, sebab sistem transaksi digital dengan e-money melibatkan penggunaan perangkat seluler terutama smartphone dan tablet, untuk melengkapi berbagai jenis transaksi dan penggunaannya tergolong praktis, fleksibel dan mudah digunakan semua orang. Kemajuan teknologi digital dalam industri perbankan saat ini merupakan suatu isu strategis utama bagi sektor perbankan, baik dalam hal peluang pengembangan bisnis bank dan dalam aspek ancaman terhadap masalah keberadaan bisnis bank (Dermine, 2016).

Layanan perbankan secara digital tak hanya mendorong pertumbuhan ekonomi di Indonesia, namun juga mengubah praktik bisnis dan mengganti metode pembiayaan tradisional. Layanan keuangan digital akan membuat akses sistem keuangan semakin meningkat sehingga memberikan manfaat bagi ekonomi nasional. Digitalisasi sistem keuangan dan teknologi disebut financial technology (fintech) yang merupakan inovasi sistem keuangan secara digital agar masyarakat dapat dengan mudah mengakses produk dan layanan keuangan dan melemahkan barrier to entry (Bank Indonesia, 2018).

Berdasarkan Peraturan BI No.19/12/PBI/2017, Tentang Penyelenggaraan Teknologi Finansial, bahwa ekosistem teknologi finansial perlu terus dimonitor dan dikembangkan untuk mendukung terciptanya stabilitas moneter, stabilitas sistem keuangan, serta sistem pembayaran yang efisien, lancar, aman, dan handal mendukung pertumbuhan ekonomi nasional yang berkelanjutan dan inklusif. Fintech mengacu pada layanan keuangan atau produk inovatif yang dikirim melalui teknologi (mobile, internet) yang luas. Namum ada hal-hal yang perlu sehingga tidak semua usaha fintech akan berhasil karena adanya faktor internal maupun eksternal, faktor keberhasilan fintech dengan prinsip LASIC (Low margin, Asset light, Scalable, Innovative, and Compliance easy), Fintech akan mewujudkannya biaya bisnis dan margin laba yang lebih 
rendah serta menyediakan potensi pasar yang sangat besar untuk lembaga keuangan dan perbankan (Chuen, 2015).

Uang elektronik diatur dalam Peraturan Bank Indonesia No.11/12/PBI/2009, sebagaimana telah diubah terakhir dengan PBI No.18/17/PBI/2016 yang menyatakan uang elektronik (electronic money) adalah, sebagai alat pembayaran yang memenuhi unsur-unsur, yaitu a) diterbitkan atas dasar nilai uang yang disetor terlebih dahulu oleh pemegang kepada penerbit, b) nilai uang disimpan secara elektronik dalam suatu media seperti server atau chip, c) digunakan sebagai alat pembayaran kepada pedagang yang bukan merupakan penerbit uang elektronik tersebut; dan d) nilai uang elektronik yang disetor oleh pemegang dan dikelola oleh penerbit bukan merupakan simpanan sebagaimana dimaksud dalam undang-undang yang mengatur mengenai perbankan.

Uang elektronik merupakan uang tunai tanpa ada fisik (cashless money), yang nilai uangnya berasal dari nilai uang yang disetor terlebih dahulu kepada penerbitnya, kemudian disimpan secara elektronik dalam suatu media elektronik berupa server (hard drive) atau kartu chip, yang berfungsi sebagai alat pembayaran non tunai kepada pedagang yang bukan penerbit uang elektronik yang bersangkutan. Nilai uang (monetary value) pada uang elektronik tersebut berbentuk elektronik dalam nilai elektronik yang didapat dengan cara menukarkan sejumlah uang tunai atau pendebetan rekeningnya di bank untuk kemudian disimpan secara elektronik dalam media elektronik berupa kartu penyimpan dana atau stored value card (Rachmadi, 2017).

Semakin pesatnya perkembangan teknologi yang mendukung transaksi di era digital saat ini, masyarakat mulai banyak dibanjiri dengan berbagai macam produk dan layanan, seiring dengan banyaknya transaksi digital, penggunaan e-money menjadi hal yang umum digunakan dalam kehidupan sehari-hari. Keuntungan penggunaan e-money, antara lain : mengurangi peredaran uang palsu di masyarakat, mencegah risiko pencurian atau perampokan karena membawa uang tunai dalam jumlah banyak, lebih akurat karena dilakukan oleh komputer atau mesin, tidak perlu menunggu uang kembalian karena nominal uang Anda akan langsung dipotong, proses transaksi bisa dilakukan dengan relatif lebih cepat.

\section{Cashless Society}

Sistem cashless society tidak lagi menggunakan uang fisik dalam bertransaksi, melainkan melalui media elektronik perpindahan informasi finansial secara digital, dalam bertransaksi sehari-hari, masyarakat tidak menggunakan uang tunai/fisik, melainkan uang digital. Sistem cashless society sudah tidak bisa dihindari lagi, mau tidak mau harus beradaptasi dan menerima teknologi digital sebagai. Dalam tiga tahun rekahir berkembang sistem pembayaran yang terintegrasi dengan teknologi, salah satunya adalah sistem pembayaran dengan teknologi QR Code (Quick Respnse Code) atau QR Payment merupakan sistem pembayaran elektronik dengan menandai $Q R$ Code, namun model sistem $Q R$ Code belum relatif di Indonesia, model pembayaran ini diharapkan menjadi sistem pembayaran yang digunakan di Indonesia, terbukti dari maraknya industri jasa keuangan atau perbankan mengembangkan $Q R$ Code sistem pembayaran tidak perlu mengunakan mesin EDC (Electronic Data Capture) atau alat pengesek kartu baik kartu debit maupun kartu kredit disebut dengan sistem cashless society.

Perkembangan sistem pembayaran untuk memaksimalkan sistem pembayara yang inovatif, aman, efisien dan mudah digunakan mulai dari penggunaan instrumen pembayaran berbasis kertas (paper based), mengunakan kartu (card based) hingga pembayaran secara elektronik (electronic based) termasuk perkembangan instrument pembayaran dari uang tunai menjadi non tunai berbasis cashless society. Kemajuan dan perkembangan instrumen pembayaran yang terintegrasi dengan teknologi informasi perbankan saat ini menjadi pilihan 
utama bagi pelaku bisnis dan menjadi alat penghubung yang terintegrasi secara online antara organisasi, perusahaan dangan pelanggan atau nasabah. Salah satu layanan teknologi digital perbankan sistem cashless society.

Sistem cashless menuntut penggunanya untuk dapat berinteraksi tanpa menggunakan perangkat elektronik baik berupa mesin ATM, mesin EDC bentuk kartu kredit, kartu debit, maupun payment gateaway. Transformasi perubahan menjadi cashless society lebih praktis, aman dan nyaman digunakan tidak perlu membawa uang fisik dengan jumlah uang yang besar. Selembar kartu plastik yang memiliki seluruh catatan keuangan kita dalam chip magnetic-nya dan sudah banyak masyarakat yang merasakan dampak positif dari cashless society. Cashless society juga berpotensi untuk mengurangi transaksi menggunakan uang palsu, mengurangi jumlah uang tunai yang beredar sehingga mengurangi biaya cetak uang fisik pula. Dampak lainnya dari cashless society adalah penurunan biaya transaksi dan efektivitas waktu yang tercipta dengan kebiasaan cashless society.

\section{Infrastruktur Uang Elektronik}

Instrumen pembayaran transaksi ekonomi dan keuangan terus mengalami perubahan. Kemajuan teknologi dalam instrument pembayaran menggeser peranan uang tunai sebagai alat pembayaran ke dalam bentuk pembayaran non tunai yang lebih efisien dan ekonomis. Pembayaran non tunai umumnya dilakukan dengan cara mentransfer antar bank maupun transfer intra bank melalui jaringan internal bank sendiri. Selain itu pembayaran non tunai dilakukan dengan kartu sebagai alat pembayaran seperti kartu ATM/Debit dan kartu kredit.

Instrumen pembayaran yang digunakan dalam artikel ilmiah ini adalah instrumen pembayaran non tunai, karena relatif lebih aman, selain itu juga dapat meningkatkan efektifitas dan efisiensi sistem pembayaran karena transaksinya lebih murah, cepat, dan mudah sehingga dapat meningkatkan produktivitas perekonomian termasuk menjaga stabilitas sistem keuangan menggunakan Alat pembayaran Menggunakan Kartu (APMK), yakni kartu ATM/debet dan kartu kredit yang bersifat account based. alat pembayaran menggunakan kartu yang akan dianalisis dibatasi pada dua jenis kartu yaitu kartu kredit dan kartu debet. alat pembayaran menggunakan kartu, diatur dalam Peraturan Bank Indonesia No. 14/2/PBI/2012, menguraikan bahwa jumlah uang beredar mengunakan APMK adalah jumlah uang beredar dalam arti luas yang disimbolkan dengan $\mathrm{M} 2$.

Instrumen sistem pembayaran sebagai leading indicator stabilitas sistem keuangan diharapkan mampu mengidentifikasi guncangan-guncangan yang menjadi sumber fluktuasi atau ketidakstabilan kondisi sistem keuangan di Indonesia. Dengan teridentifikasinya guncanganguncangan ini, dapat diketahui kebijakan apa yang tepat untuk stabilisasi fluktuasi tersebut. Hal ini diharapkan dapat menjadi informasi yang berguna bagi pengambil keputusan kebijakan ekonomi dan keuangan Indonesia (Untoro, 2014).

\section{PENGEMBANGAN HIPOTESIS}

\section{Pengaruh Transaksi Digitalisasi Uang Elektronik Terhadap Cashless Society Dan Infrastruktur Uang Elektronik Sebagai Variabel Pemodarasi}

Berkembangnya bisnis startup di Indonesia juga mempengaruhi transaksi uang elektronik yang semakin meningkat. Saat ini banyak perusahaan perbankan maupun perusahaan lainnya seperti jasa menggunakan uang elektronik, dan untuk meningkatkan kenyamanan para pengguna uang elektronik, maka diharapkan turut sertanya semua pihak dalam mensosialisakan transaksi dengan menggunakan uang elektronik maka tidak menutup kemungkinan jika suatu 
saat nanti negara Indonesia menjadi negara yang menerapkan cashless society untuk semua masyarakatnya, (Tazkiyyaturrohmah, 2018).

Bedasarkan landasan teori uang elektronik yang telah diauraikan diatas, maka hipotesis yang dikembangkan adalah, antara lain :

H1: Diduga transaksi uang elektronik berpengaruh terhadap chesless social

H2 : Diduga uang elektronik beredar berpengaruh terhadap chesless social

H3 : Diduga digitalisasi uang elektronik berpengaruh terhadap chesless social

H4 : Diduga infrastruktur uang elektronik berpengaruh terhadap chesless social

H5 : Diduga secara simulltan transaksi uang elektronik, uang elektronik beredar, digitalisasi uang elektronik dan infrastruktur uang elektronik berpengaruh terhadap chesless social

\section{Pengaruh Transaksi Digitalisasi Uang Elektronik Terhadap Cashless Society Dan Infrastruktur Uang Elektronik Sebagai Variabel Pemodarasi}

Bank - bank sentral di dunia saat ini mendorong penggunaan instrumen pembayaran non tunai. Hal ini dikarenakan pembayaran non tunai relatif lebih aman, selain itu juga dapat meningkatkan efektifitas dan efisiensi sistem pembayaran karena transaksinya lebih murah, cepat, dan mudah sehingga dapat meningkatkan produktivitas perekonomian negara. Perkembangan sistem pembayaran ini didukung dengan adanya Alat Pembayaran Dengan Menggunakan Kartu (APMK). Jenis alat pembayaran dengan menggunakan kartu APMK yang akan dianalisis dalam penelitian ini dibatasi pada tiga jenis kartu yaitu kartu kredit, kartu debet, serta kartu ATM. Pendekatan ini dipakai karena sesuai dengan definisi APMK dalam Peraturan Bank Indonesia (PBI) No. 6/30/PBI/2004 tentang Penyelenggaraan Alat Pembayaran dengan Menggunakan Kartu serta ketersediaan data dari Bank Indonesia. Selain itu, ketiga jenis kartu tersebut sangat luas digunakan dan banyak diketahui oleh masyarakat Indonesia,

Instrumen pembayaran dengan non tunai menggunakan informasi alat pembayaran menggunakan kartu dan uang elektronik. APMK ada dua jenis kartu yaitu kartu debet dan kartu kredit. Sesuai dengan definisi APMK dalam Peraturan Bank Indonesia No.14/2/PBI/2012, data yang digunakan dengan jumlah uang beredar dalam arti sempit (M1) dan uang beredar luas (M2). Berdasarkan uraian teori instrumen pembayaran dengan non tunai diatas, maka hipotesis dapat dikembangkan, antara lain :

H6 : Diduga transaksi uang elektronik berpengaruh terhadap chesless social yang dimderasi oleh infrastruktur uang elektronik

H7 : Diduga uang elektronik beredar berpengaruh terhadap chesless social yang dimderasi oleh infrastruktur uang elektronik

H8 : Diduga digitalisasi uang elektronik berpengaruh terhadap chesless social yang dimderasi oleh infrastruktur uang elektronik

\section{METODOLOGI \\ Jenis dan Sumber Data}

Jenis penelitian ini adalah penelitian kuantitatif, menggunakan data sekunder bentuk time series. Data diperoleh dari publikasi website Bank Indonesia situs www.bi.go.id, berupa data uang elektronik, infrastruktur uang elektronik, APMK (Alat Pembayaran Mengunakan Kartu), peredaran uang, periode Januari $2014-2019$, jumlah data 67.

\section{Metode dan Analisis}

Analisis dan pengujuan data menggunakan aplikasi SPSS V.24, untuk menguji statistik deskriptif, menguji asumsi klasik yakni uji normalitas data, uji asumsi heteroskedastisitas, 
autokorelasi dan multikolinearitas sebagai salah satu syarat menggunakan persamaan regresi berganda, kemudian dilanjutan pengujian analisis hipotesis untuk menguji pengaruh variabel bebas terhadap variabel terikat melalui Uji T, Uji F dan Uji Determinasi.

\section{Operasional Pengukuran Variabel \\ Variabel Independen}

Variabel independen mengunakan tiga kelompok variabel, yaitu digitalisasi jasa keuangan dengan uang elektronik, cashles society dan instrumen pembayaran yang berhubungan dengan peredaran uang.

\section{Digitalisasi Transaksi Uang Elektronik}

Digitalisasi jasa keuangan sebagai dasar komponen transaksi uang melakukan pembayaran dan mutasi saldo ke rekening lainnya secara online dan digitalisasi, seperti; ATM (Automatic Teller Machine), internet banking, mobile banking, phone banking, sms banking. Analis digitalisasi jasa keuangan dari aktifitas transaksi uang elektronik menggunakan data volume transaksi uang elektronik, nominal transaksi uang elektronik dan infrastruktur uang elektronik. Dalalm teori kuantitas uang, kecepatan perputaran uang (velocity of money) dinyatakan secara lebih jelas sebagai pendapatan nominal ( $P$ Y) dibagi dengan jumlah uang (M): $V=(\mathrm{P} Y) / M$ Dengan mengalikan kedua sisi persamaan dengan $\mathrm{M}$, kita mendapatkan persamaan pertukaran (equation of change), yang menghubungkan pendapatan nominal $(P Y)$ dengan jumlah uang $(M)$ dan kecepatan perputaran uang $(V)$ : $M$ $\mathrm{V}=\mathrm{P} \mathrm{Y}$, teori permintaan uang atau yang lebih dikenal dengan teori kuantitas uang yang digagas oleh tokoh klasik, Irving Fischer; (Miskhin, 2008) dirumuskan sebagai berikut :

$$
M . V=P . T \text {. }
$$

Dengan keterangan; $M$ (jumlah uang beredar), V (velocity of money atau kecepatan pergerakan uang), $\mathrm{P}$ (harga) dan $\mathrm{T}$ (jumlah transaksi yang terjadi didalam perekonomian).

\section{Cashless Society}

Analisis cashles society merupakan transaksi keuangan yang tidak lagi menggunakan uang tunai, tetapi sudah dalam bentuk kartu, baik berupa kartu kredit, kartu debit, maupun payment gateaway. cashles society menggunakan data jumah uang elektronik beredar dan APMK (Alat Pembayaran Menggunakan Kartu). Rumus yang digunakan untuk cashles society terdiri dari :

Cashless Society Uang Elektronik $(\Sigma x i)=X_{1}+X_{2}+X_{3}+\ldots X_{12}$

Cashless Society APMK $=\sum$ Transaksi $A T M+\sum$ Transaksi Kartu Kredit

\section{Instrumen Pembayaran Non Tunai}

Pendekatan instrument pembayaran non tunai dengan Peraturan Bank Indonesia No. 6/30/PBI/2004 tentang Penyelenggaraan Alat Pembayaran dengan Menggunakan Kartu (APMK), intrumen pembayaran APMK yang dibatasi pada dua jenis kartu yaitu kartu kredit dan kartu debet kredit. Jumlah uang beredar sesuai Peraturan Bank Indonesia No.14/2/PBI/2012, jumlah uang beredar dalam arti sempit dengan simbol M1 dan luas dengan M2. Komponen dan perhitungan besaran moneter M1 dan M2 adalah sebagai berikut :

M1 =Uang Kartal (Currency) + Uang Giral (Demand Deposit)

$\mathrm{M} 2$ = M1+ simpanan berjangka+ simpanan 


\section{HASIL DAN PEMBAHASAN}

\section{Hasil Pengolahan Data Penelitian}

Hasil pengujian hipotesis penelitian secara parsial dan simultan ditunjukkan dalam table 1 dibawah ini

Tabel 1. Hasil Pengujian Secara Parsial dan Simultan

\begin{tabular}{lccrc}
\hline Variable & $\begin{array}{c}\text { Unstandardized } \\
\text { Coefficients }\end{array}$ & $\begin{array}{c}\text { Standardized } \\
\text { Coefficients }\end{array}$ & T-Test & $\begin{array}{c}\text { Probabilitas } \\
\text { (Sig. a 0,05) }\end{array}$ \\
\hline (Constant) & 1,660 & & 7,428 & 0,000 \\
\hline Transaksi U. Elektronik & 0,929 & 2,010 & 2,903 & 0,005 \\
\hline Uang Elektronik Beredar & $-1,470$ & $-0,706$ & $-10,327$ & 0,000 \\
\hline Digitalisasi U. Elektronik & $-0,543$ & $-1,630$ & $-2,818$ & 0,007 \\
\hline Infrastruktur U. Elektronik & $-1,463$ & $-1,466$ & $-4,001$ & 0,000 \\
\hline R Square & & & & 0,759 \\
Adjusted R Square & & & & 0,744 \\
F-Test & & & & 48,133 \\
Probability & & & 0,000 \\
\hline
\end{tabular}

a. Dependent Variable: Chesless Social

Sumber data BI, diolah dengan aplikasi SPSS V.24, (2019)

Hasil pengujian hipotesis berdasarkan Tabel.1 diatas, membuktikan bahwa transaksi digitalisasi uang elektronik berpengaruh dan signifikan terhadap cashless society, terbukti dari pengujian masing-masing variabel peneitian, antara lain : 1) transaksi uang elektronik berpengaruh signifikan terhadap chesless, 2) uang elektronik beredar berpengaruh signifikan terhadap chesless, 3) digitalisasi uang elektronik berpengaruh signifikan terhadap chesless, 4) infrastruktur uang elektronik berpengaruh signifikan terhadap chesless society dan 5) simultan berpengaruh signifikan terhadap chesless. Hasil uji masing-masing dapat diformulasikan dalam regresi berganda secara parsial sebagai berikut :

$Y=\beta 0+\beta 1$ TUE $+\beta 2$ UEB $+\beta 3$ DUE $+\beta 4$ IUE $+\varepsilon$

$Y=1,660+0,929$ TUE $-1,470$ UEB $-0,543$ DUE $-1,463$ IUE $+\varepsilon$

\section{Pembahasan Pengujian Secara Parsial dan Simultan}

Interpretasi hasil uji parsial pengaruh uang elektronik (transaksi uang elektronik, uang elektronik beredar, digitalisasi uang elektronik, infrastruktur uang elektronik) terhadap chesless society sebagai berikut:

$\mathrm{H} 1$ = Transaksi Uang Elektronik (TUE), H1 terbukti bahwa transaksi uang elektronik berpengaruh signifikan terhadap Chesless Society, dibuktikan berdasarkan nilai signifikansi Uji_T sebesar 0,005 $<0,05$, tingkat kepercayaan 95 , didukung dengan niai coefficients 0,929 artinya setiap peningkatan penggunaan transaksi uang elektronik Rp 1,- akan meningkatkan jumah transaksi chesless society sebesar Rp 929,- atau nilai chesless society naik sebesar $92,9 \%$. 
$\mathrm{H} 2$ = Uang Elektronik Beredar (UEB), H2 terbukti bahwa uang elektronik beredar berpengaruh signifikan dan negatif terhadap Chesless Society, , dibuktikan berdasarkan nilai signifikansi Uji_T sebesar 0,000 < 0,05, tingkat kepercayaan 95\%, didukung dengan niai coefficients sebesar $-1,470$ artinya setiap peningkatan uang elektronik beredar $\mathrm{Rp}$ 1,- akan menurunkan jumah chesless society yang beredar sebesar Rp 1.470,- atau nilai chesless society turun sebesar $147 \%$. Terjadinya penurunan nilai chesless society dikarenakan bahwa peredaran nilai nominal jumlah uang elektronik beredar dimasyarakat lebih besar dari pada jumlah nilai nominal saving money masyarakat atau jumlah uang yang disimpan masyarakat dibank reatif lebih rendah, sehingga penggunaan uang untuk transaksi chesless society akan berkurang.

$\mathrm{H} 3$ = Digitalisasi Uang Elektronik (DUE), H3 terbukti bahwa digitalisasi uang elektronik berpengaruh dan signifikan terhadap Chesless Society, dibuktikan berdasarkan nilai signifikansi Uji_T sebesar 0,007 <0,05, tingkat kepercayaan 95\%, didukung dengan niai coefficients $-0,543$ artinya setiap peningkatan pengunaan transaksi dengan digitaisasi uang elektronik $\mathrm{Rp} 1,-$ akan menurunkan jumah chesless society yang beredar sebesar Rp 543,- atau nilai chesless society turun sebesar $54,3 \%$.

$\mathrm{H} 4$ = Infrastruktur Uang Elektronik (IUE), H4 terbukti bahwa infrastruktur uang elektronik berpengaruh signifikan terhadap Chesless Society, dibuktikan berdasarkan nilai signifikansi Uji_T sebesar $0,000<0,05$, tingkat kepercayaan 95\%, didukung dengan niai coefficients $-1,463$ artinya setiap peningkatan fasiitas dan layanan infrastruk uang elektronik Rp 1,- akan menurunkan jumah chesless society yang beredar sebesar Rp 1.463 ,- atau nilai chesless society turun sebesar $146,3 \%$.

$\mathrm{H} 5=$ Pengujian Hipotesis ke-5 secara simultan terbukti bahwa Transaksi Uang Elektronik, Uang Elektronik Beredar, Digitalisasi Uang Elektronik, Infrastruktur Uang Elektronik berpengaruh signifikan terhadap Chesless Society. Secara sumultan pengaruhnya sebesar $74,4 \%$, artinya jika jumah transaksi digitalisasi uang elektronik semakin meningkat maka pengunann transaksi dengan cashless society akan meningkat juga

\section{Hasil Pengujian Interaksi Variabel Pemoderasi}

Pengujian secara simultan (uji-t), uji parsial (uji-f) dan uji determinasi (D2) interkasi variable pemoderasi yaitu analisis pengaruh digitalisasi uang elektronik terhadap cashless society dan infrastruktur uang elektronik sebagai variabel pemodarasi ditunjukkan dalam tabel 2 dibawah ini.

Tabel 2. Hasil Pengujian Interakasi Variabel Pemoderasi

\begin{tabular}{lccrc}
\hline Variable & $\begin{array}{c}\text { Unstandardized } \\
\text { Coefficients }\end{array}$ & $\begin{array}{c}\text { Standardized } \\
\text { Coefficients }\end{array}$ & T-Test & $\begin{array}{c}\text { Probabilitas } \\
\text { (Sig. } \alpha \text { 0,05) }\end{array}$ \\
\hline (Constant) & 0,855 & - & 20,708 & 0,000 \\
\hline Z-1 (TEU x CLS) & 0,276 & 1.271 & 5,522 & 0,000 \\
\hline Z-2 (UEB x CLS) & $-1,264$ & $-0,698$ & $-7,508$ & 0,000 \\
\hline Z-3 (DUE x CLS) & $-0,442$ & $-0,956$ & $-4,077$ & 0,000 \\
\hline$R$ Square & & & & 0,588 \\
Adjusted $R$ Square & & & & 0,568 \\
F -Test & & & 29.469 \\
Probability & & & & 0,000 \\
\hline
\end{tabular}

a. Dependent Variable: Chesless Social

b. Moderating Variable : Infrastruktur Uang Elektronik

Sumber data BI, diolah dengan aplikasi SPSS V.24, (2019) 
Tabel.2 Hasil pengujian hipotesis interaksi variabel pemoderasi (Z) secara parsial dan simultan diformulasikan dalam regresi berganda secara parsial sebagai berikut :

$$
\begin{aligned}
& Y=\beta 0+\beta 1(\text { TEU } \times C L S) \times C L S+\beta 2(\text { UEB } \times \text { CLS) } \times C L S+\beta 3 \text { (DUE } \times C L S)+\varepsilon \\
& Y=0,855+0,276(\text { TEU } \times \text { CLS) }-1,264 \text { (UEB } \times \text { CLS) }-0,442 \text { (DUE } \times C L S)+\varepsilon
\end{aligned}
$$

\section{Pembahasan Hasil Pengujian Variabel Pemoderasi (Z)}

Interpretasi hasil pengujian variabel pemoderasi infrastruktur uang elektronik (Z) :

H6: Variabel Moderasi ke-1 (TEU x CLS) memiliki koefisien parameter 0,276 pada tingkat signifikansinya 0,000 $<0,05$, tingkat kepercayaan $95 \%$. H6 Terbukti; bahwa Transaksi Uang Elektronik berpengaruh signifikan terhadap Chesless Society yang dimoderasi infrastruktur uang elektronik, artinya interaksi variabel moderasi infrastruktur uang elektronik mampu memperkuat pengaruh transaksi uang elektronik terhadap chesless society sebesar $27,6 \%$. Jika infrastruktur uang elektronik semakin baik dan mengikuti kebutuhan nasabah/masyakat maka transaksi uang elektronik semakin meningkat dan masyarakat akan memilih transaksi mengunakan model chesless society.

H7 : Variabe Moderasi ke-2 (UEB x CLS) memiliki koefisien parameter -1,264 pada tingkat signifikansinya $0,000<0,05$, tingkat kepercayaan $95 \%$. H7 Terbukti; bahwa uang elektronik beredar berpengaruh signifikan terhadap chesless society yang dimoderasi infrastruktur uang elektronik, artinya interaksi variabel moderasi infrastruktur uang elektronik mampu memperkuat pengaruh uang elektronik beredar terhadap chesless society sebesar $-126,4 \%$. Jika infrastruktur uang elektronik meningkat Rp1,00 maka transaksi uang elektronik beredar semakin berkurang dan mengurangi peredaran uang elektronik chesless society sebesar Rp 1.264,00.

H8: Variabe Moderasi ke-3 (DUE x CLS) memiliki koefisien parameter $-0,442$ pada tingkat signifikansinya 0,000 $<0,05$, tingkat kepercayaan 95\%. H8 Terbukti; bahwa digitalisasi uang elektronik berpengaruh signifikan terhadap chesless society yang dimoderasi infrastruktur uang elektronik, artinya interaksi variabel moderasi infrastruktur uang elektronik mampu memperkuat pengaruh digitalisasi uang elektronik terhadap chesless society sebesar $-44,2 \%$. Jika digitalisasi uang elektronik meningkat Rp1,00 maka transaksi uang elektronik beredar semakin berkurang dan mengurangi peredaran uang elektronik chesless society sebesar Rp 442,00.

\section{KESIMPULAN DAN REKOMENDASI KEBIJAKAN Kesimpulan}

Hasil pengujian hiptesis bahwa 1) transaksi uang elektronik terbukti berpengaruh signifikan terhadap Chesless Society, sebesar 92,9\%. 2) Uang Elektronik Beredar berpengaruh signifikan dan negatif terhadap Chesless Society, sebesar -1,470, 3) Digitalisasi Uang Elektronik berpengaruh dan signifikan terhadap Chesless Society, sebesar 54,3\%. 4) Infrastruktur Uang Elektronik berpengaruh signifikan terhadap Chesless Society, sebesar 146,3\%. 5) Secara simultan terbukti bahwa Transaksi Uang Elektronik, Uang Elektronik Beredar, Digitalisasi Uang Elektronik, Infrastruktur Uang Elektronik berpengaruh signifikan terhadap Chesless Society. Secara sumultan pengaruhnya sebesar $74,4 \%$, artinya jika jumah transaksi digitalisasi uang elektronik semakin meningkat maka pengunann transaksi dengan cashless society akan meningkat.

Interpretasi hasil pengujian variabel pemoderasi infrastruktur uang elektronik (Z) terbukti bahwa : 1) Interaksi variabel moderasi infrastruktur uang elektronik mampu memperkuat 
pengaruh transaksi uang elektronik terhadap chesless society sebesar $27,6 \%$, 2) Interaksi variabel moderasi infrastruktur uang elektronik mampu memperkuat pengaruh uang elektronik beredar terhadap chesless society sebesar $-126,4 \%$. 3) Interaksi variabel moderasi infrastruktur uang elektronik mampu memperkuat pengaruh digitalisasi uang elektronik terhadap chesless society sebesar $-44,2 \%$. Jika digitalisasi uang elektronik meningkat Rp1,00 maka transaksi uang elektronik beredar semakin berkurang dan mengurangi peredaran uang elektronik chesless society sebesar Rp 442,00.

\section{Rekomendasi Kebijakan}

Setiap peningkatan penggunaan transaksi uang elektronik akan meningkatkan jumah transaksi chesless society atau nilai chesless society naik, Terjadinya penurunan nilai chesless society dikarenakan bahwa peredaran nilai nominal jumlah uang elektronik beredar dimasyarakat lebih besar dari pada jumlah nilai nominal saving money masyarakat atau jumlah uang yang disimpan masyarakat dibank reatif lebih rendah, sehingga penggunaan uang untuk transaksi chesless society akan berkurang. Peningkatan pengunaan transaksi dengan digitaisasi uang elektronik akan menurunkan jumah chesless society yang beredar atau nilai chesless society turun

Rekmendasi kebijakan untuk meningkatkan penggunaan uang elektronik dan cashless society perlu ditingkatakan melalui sosialisasi pada daerah tertentu agar termotifasi menjadi pelaku cashless society dan menjadi pola kebiasaan masyarakat dalam bertransaksi dengan uang elektronik hingga pada akhirnya masyarakat sudah terbiasa dengan menggunakan uang elektronik dibandingkan uang tunai.

\section{DAFTAR PUSTAKA}

\section{Artikel dalam Jurnal}

Bank Indonesia. 2018. Kajian Stabilitas Keuangan. Penguatan Ketahanan Stabilitas Sistem Keuangan Kajian Stabilitas Keuangan Mendorong Momentum Pertumbuhan, No. 31, September 2018.

Chuen, D.L.K., and Teo, E.G.S. 2015, "Emergence of fintech and the LASIC principles", The Journal of Financial Perspectives: Fintech, Sim Kee Boon Institute for Financial. Economics, Singapore Management University.

Dermine J. 2016. 'Digital Banking and Market Disruption: A Sense of Deja' Vu?' Financial Stability Review, Banque de France, April, p. 17-24.

Handayani, Tri dan Lastuti. 2017. Perkembangan Hukum Sektor Jasa Keuangan Dalam Upaya Percepatan Pertumbuhan Ekonomi Nasional. Jurnal De Lega Lata, Volume 2. Nomor 2. Juli-Desember.

Hassim, Andreas 2017. Revolusi Digital: Sebuah Keniscayaan. Probank, Membangun Perbankan Profesional, Perhimpunan Bank Nasional (Perbanas). No.130 Tahun XXXIV September-Oktober 2017. Jakarta.

Ninda, Nastiti Lintangsari, Nisaulfathona Hidayati, Yeni Purnamasari. 2015.Analisis Pengaruh Instrumen Pembayaran Nontunai Terhadap Stabilitas Sistem Keuangan di Indonesia, Universitas Diponegoro.

Rachmadi, Usman. 2017. Karakteristik Uang Elektronik Dalam Sistem Pembayaran. Jurnal Yuridika Fakultas Hukum Universitas Airlangga, Vol.32, No.1, Hal. 134-166. 
Schumann, C and Tittmann, C. 2015, Digital Business Transformation in the Context of Knowledge Management, Academic Conferences International Limited, Kidmore End, 09, pp. 675

Tazkiyyaturrohmah, Rifqy. 2018. Eksistensi Uang Elektronik Sebagai Alat Transaksi Keuangan Modern. Jurnal Muslim Heritage, Vol. 3, No.1, Hal. 21-39.

Untoro, Priyo R. Widodo, Wahyu Yuwana. 2014. Kajian Penggunaan Instrumen Sistem Pembayaran Sebagai Leading Indicator Stabilitas Sistem Keuangan. Working Paper, Bank Indonesia. WP/5/2014

\section{Buku}

Miskhin, Frederic S. 2008. Buku 1 Ekonomi Uang, Perbankan, dan Pasar Keuangan. Jakarta: Salemba Empat.

\section{Perundang-Undangan dan Peraturan}

Peraturan Bank Indonesia No.14/2/PBI/2012 tanggal 6 Januari 2012 tentang Perubahan Atas Peraturan Bank Indonesia Nomor 11/11/PBI/2009 tentang Penyelenggaraan Kegiatan Alat Pembayaran Dengan Menggunakan Kartu

Peraturan Bank Indonesia Nomor 18/17/PBI/2016 Tentang Perubahan Kedua Atas Peraturan Bank Indonesia Nomor 11/12/PBI/2009 Tentang Uang Elektronik (Lembaran Negara Republik Indonesia Tahun 2016 Nomor 179, Tambahan Lembaran Negara Republik Indonesia Nomor 5925).

Peraturan Bank Indonesia Nomor 19/12/PBI/2017 Tentang Penyelenggaraan Teknologi Finansial. 